\title{
Efektivitas Blok Transversus Abdominis Plane Pasca Operasi Caesar
}

\author{
Gusti Muhammad Fuad Suharto, Rory Denny Saputra \\ Departemen Anestesiologi dan Terapi Intensif fakultas Kedokteran Universitas Lambung Mangkurat-RSUD Ulin \\ Banjarmasin
}

\begin{abstract}
Abstrak
Operasi caesar merupakan prosedur bedah yang paling umum dilakukan di seluruh dunia. Operasi ini menyebabkan nyeri pasca operatif sedang hingga berat sebagai akibat insisi pfannenstiel yang umumnya dikaitkan dengan rasa nyeri pada uterus dan somatik pada dinding abdomen. Analgesia pasca operasi yang memadai pada pasien obstetrik sangat penting karena mereka memiliki kebutuhan pemulihan bedah yang berbeda, yaitu meliputi menyusui dan perawatan bayi baru lahir, hal ini dapat terganggu jika analgesia yang diberikan tidak memuaskan. Rejimen analgesik pasca operasi yang ideal harus efektif tanpa mempengaruhi ibu untuk merawat neonates dan dengan efek transfer obat yang seminimal mungkin melalui ASI. Saat ini banyak cara yang paling aman dan efektif dari intervensi manajemen nyeri pasca operasi seperti anestesi lokal dengan infiltrasi kulit, analgesia epidural, dan blok bidang seperti blok transversus abdominis plane (TAP) dan blok ilioinguinal-iliohipogastrik (II-IH). Blok TAP merupakan teknik anestesi regional dimana serabut saraf aferen yang menginervasi dinding abdomen bagian anterolateral diblokir dengan mengguakan anestesi lokal di bidang transversus abdominalis. Potensinya dalam meningkatkan kualitas dan durasi analgesia setelah berbagai operasi abdomen bawah sudah tidak bisa dipungkiri lagi. Sekarang, dengan bantuan USG menjadikan blok TAP sebagai metode yang aman dan efektif untuk memberikan analgesia pasca operasi caesar dibandingkan dengan perawatan standar pasca operasi. Selain itu, blok TAP juga dikaitkan dengan pengurangan konsumsi opioid, peningkatan kepuasan pasien, dan efektif untuk mengurangi nyeri dibandingkan dengan teknik analgesia lainnya.
\end{abstract}

Kata kunci: analgesia; anestesi, blok transversus abdominis plane (TAP); nyeri pasca operasi; operasi caesar

\section{Efficacy of Transversus Abdominis Plane Block After Post Caesarean Section Delivery}

\begin{abstract}
Caesarean section is the most common surgical procedure performed worldwide. This operation causes moderate to severe postoperative pain as a result of pfannenstiel incision which is commonly associated with pain in the uterus and somatic in the abdominal wall. Adequate postoperative analgesia in obstetric patients is very important because they have different surgical recovery needs, which include breastfeeding and newborn care, this is can be disrupted if the analgesia given is not satisfactory. The ideal postoperative analgesic rejimen must be effective without affecting the mother to treat the neonate and with minimal effect of drug transfer through breast milk. There are currently many of the safest and effective ways of interventions for postoperative pain management such as local anesthetic skin infiltration, epidural analgesia, and field block like TAP and II-IH. TAP block is a regional anesthetic technique where afferent nerve fibers that innervate the anterolateral abdominal wall are blocked by using local anesthesia in the transverse abdominal plane area. Potential in improving the quality and duration of analgesia after various lower abdominal operations is inevitable. Now, with ultrasound guiding, the TAP block is a safe and effective method for providing analgesia post caesarean section delivery compared to standard postoperative care. In addition, TAP block is also associated with a reduction of opioid consumption, increased patient satisfaction, and is effective in reducing pain compared to other analgesia technique.
\end{abstract}

Key words: anaesthesia; analgesia; caesarean section; postoperative pain; transversus abdominis plane block 


\section{Pendahuluan}

Operasi caesar merupakan salah satu prosedur bedah yang paling umum dilakukan di seluruh dunia. Peningkatan frekuensi yang stabil dalam beberapa tahun terakhir belum sepenuhnya diklarifikasi, namun hal ini bisa disebabkan oleh banyaknya praktik obstetri, riwayat operasi caesar sebelumnya, atau tekanan dari instansi, ekonomi, sosial dan budaya. Operasi caesar menyebabkan nyeri pasca operatif sedang hingga berat sebagai akibat dari nyeri uterus dan somatik pada dinding abdomen. ${ }^{1}$

Di Amerika Serikat pada tahun 2014, sekitar 1,28 juta wanita menjalani operasi caesar, terhitung yaitu $32 \%$ dari semua kelahiran. Untuk dokter anestesi obstetrik yang merawat wanita setelah menjalani operasi caesar, pemberian analgesia pasca operatif yang efektif penting untuk beberapa alasan. Pertama, wanita menilai pencegahan rasa sakit selama dan setelah operasi caesar merupakan prioritas tertinggi mereka. Kedua, nyeri akut setelah operasi caesar dapat berkembang menjadi nyeri yang persisten, sehingga dapat menyebabkan penggunaan opioid yang lebih besar, pemulihan fungsional yang tertunda, dan peningkatan terjadinya risiko depresi post partum. Ketiga, memastikan analgesia yang efektif dapat mengoptimalkan ikatan ibu-neonatal dan menyusui setelah melahirkan. ${ }^{2}$

Nyeri menduduki peringkat tertinggi diantara hasil klinis yang tidak diinginkan terkait dengan operasi Caesar. Analgesia pasca operasi yang memadai pada pasien obstetri sangat penting karena mereka memiliki kebutuhan pemulihan bedah yang berbeda yaitu meliputi menyusui dan perawatan bayi baru lahir, ini dapat terganggu jika analgesia yang diberikan tidak memuaskan. Rejimen analgesik pasca operasi caesar yang ideal harus efektif tanpa mempengaruhi ibu untuk merawat neonatus dan dengan efek transfer obat seminimal mungkin melalui ASI. ${ }^{3}$

Menjadi suatu bentuk analgesia pasca operatif yang ideal masih belum diketahui, tetapi banyak prosedur yang dilakukan dengan anestesi spinal dan opioid yang umum digunakan untuk menghilangkan nyeri pasca operasi caesar, baik dengan pemberian intratekal atau dengan pemberian parenteral pasca operasi sebagai komponen analgesia multimodal selama periode pasca operasi. Namun mereka memiliki efek samping yang merugikan seperti mual, muntah, sedasi, pruritus, dan risiko depresi pernapasan ibu yang tertunda, yang semuanya mengurangi kepuasan pasien secara keseluruhan. Selain itu, efek samping terkait opioid ini dapat menghasilkan masalah lain untuk ibu yang baru melahirkan seperti keterlambatan inisiasi menyusui dini dan gangguan ikatan ibu/bayi. ${ }^{4}$

Saat ini banyak cara yang paling aman dan efektif dari intervensi untuk manajemen nyeri pasca operasi caesar seperti anestesi lokal dengan infiltrasi kulit, analgesia epidural, dan blok bidang seperti tranversus abdominis plane (TAP) dan ilioinguinal-iliohypogastric (II-IH).4 Oleh sebab itu perlu diketahui keefektivan dari blok TAP sebagai salah satu rejimen manajemen nyeri pasca operasi caesar.

\section{Blok Transversus Abdominis Plane}

Blok tranversus abdominis plane (TAP) pertama kali diperkenalkan oleh Rafi pada tahun 2001 sebagai teknik yang dipandu melalui segitiga petit untuk mencapai bidang transversus abdominis. Ini melibatkan injeksi anestesi lokal ke dalam bidang antara otot oblikus interna dan otot tranvesus abdominis, karena saraf torakolumbal berasal dari radik spinalis T6 sampai L1 berjalan ke bidang ini dan menginervasi saraf sensorik ke anterolateral dinding abdomen. Penyebaran anestesi lokal dibidang ini dapat memblokir serabut aferen dan memberikan analgesia ke dinding abdomen anterolateral. ${ }^{5}$

Dengan kemajuan teknologi ultrasound, blok TAP secara teknis lebih mudah dan lebih aman untuk dilakukan. Oleh sebab itu, terdapat peningkatan penggunaan pada blok TAP sebagai tambahan terapi untuk analgesia setelah operasi pada bagian abdomen. Dalam dekade terakhir, telah banyak bukti yang mendukung keefektifan dari blok TAP untuk berbagai operasi pada abdomen, seperti operasi caesar, histerektomi, kolesistomi, kolektomi, prostatektomi, dan perbaikan hernia. Walaupun efek analgesiknya hanya mencakup 
nyeri somatik dengan durasi pendek, blok TAP sekali pakai memainkan peran yang berharga dalam analgesia multimodal. Bersamaan dengan infus kontinyu atau anestesi lokal liposomal dalam jangka panjang, blok TAP dapat mengatasi masalah durasi yang singkat. ${ }^{5}$

\section{Anatomi}

Anatomi yang relevan ditunjukan pada gambar 1. Pemahaman yang menyeluruh tentang anatomi dapat membantu dokter untuk menentukan lokasi injeksi, meningkatkan tingkat keberhasilan, dan mencegah komplikasi. ${ }^{5}$

Serabut saraf torakolumbal merupakan serabut saraf yang bertanggungjawab untuk inervasi kulit segmental dari dinding abdomen. Mereka terbagi menjadi ramus primer anterior dan ramus primer posterior pendek setelah keluar dari foramen intervertebra. Ramus posterior bergerak kebelakang, sedangkan ramus anterior bercabang menjadi dua untuk menginervasi kulit lateral dan anterior dinding abdomen. Dinding abdomen anterolateral terutama dipersarafi oleh ramus anterior saraf spinalis torakolumbal (T6-L1), yang menjadi interkostal (T6-T11), subkostal (T12), dan saraf ilioinguinal/iliohipogastrik (L1) (Gambar 1.(a)). Cabang-cabang ini selanjutnya bergabung di beberapa lokasi, termasuk bergabung di cabang besar pada dinding abdomen anterolateral (interkostal/pleksus TAP superior) dan pleksus yang berjalan dengan arteri iliaka sirkumfleksa profunda (pleksus TAP inferior) serta arteri epigastrik inferior profunda (pleksus aponeurosis rektus abdominis). Karena penyatuan saraf segmental tepat di atas otot tranversus abdominis, penyebaran anestesi lokal subfasia dapat memberikan analgesia dinding abdomen anterolateral. ${ }^{5}$

Ramus primer anterior dari saraf spinal T6-T12 melewati antara muskulus oblikus internus dan transversus abdominis yang kemudian menembus rektus abdominis dan berakhir sebagai cabang kulit bagian anterior, yang menginervasi anterior dari abdomen (dari linea mediana anterior sampai linea midklavikularis). Diantara ramus anterior ini, T12 melintasi muskulus kuadratus lumborum sebelum memasuki TAP, seperti yang ditunjukan pada gambar 1.(b). Cabang-cabang kulit bagian lateral berasal dari sudut kosta posterior. Selain itu, cabang-cabang kulit lateral yang juga berasal dari saraf spinal T6-T11 akan terbagi menjadi cabang-cabang anterior dan posterior, cabangcabang anterior akan menginervasi dinding abdomen menuju margin lateral rektus abdominis, sementara cabang-cabang posteriornya akan ke belakang untuk menginervasi kulit diatas latissimus dorsi. Namun, cabang kulit lateral dari T12 tidak membagi lebih jauh menjadi cabang anterior dan posterior (gambar 1.(b)). Cabang ini hanya menginervasi bagian dari wilayah gluteal dan beberapa filamennya yang terendah mencapai trochanter mayor (gambar 1.(c)). Saraf spinal dari
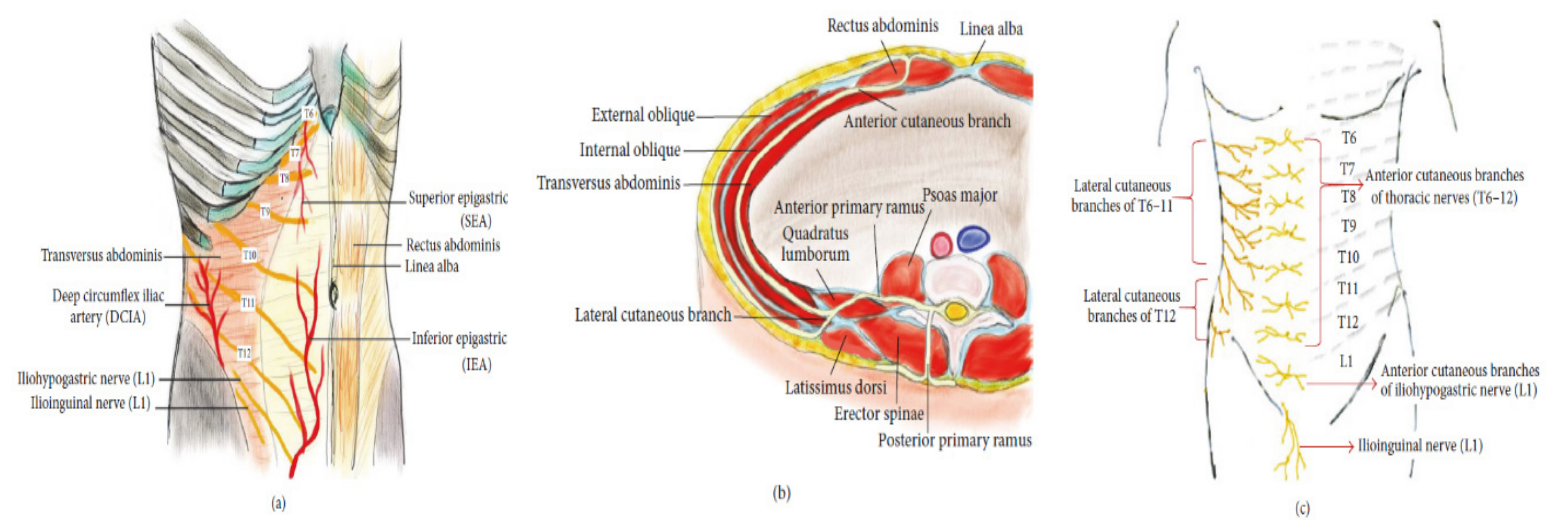

Gambar 1. Saraf spinalis torakolumbal (T6-L1) yang menginervasi abdomen anterolateral. (a) distribusi struktur neurovascular di dinding abdomen anterolateral. (b) jalur saraf spinalis torakolumbal (T12). Ini adalah bagian penampang abdomen sinistra. Ramus primer anterior dari saraf segmental terbagi menjadi cabang kutaneus anterior dan lateral, yang menginervasi dinding abdomen anterolateral. (c) distribusi segmental saraf kulit pada abdomen 
L1 akan terbagi menjadi saraf iliohipogastrik dan saraf ilioinguinal, yang menginervasi kulit daerah gluteal di belakang cabang kutaneus lateral dari $\mathrm{T} 12$, daerah hipogastrik, bagian medial atas paha, dan daerah genital. ${ }^{5}$

Karena cabang kulit lateral meninggalkan TAP posterior ke linea midaksilaris, maka injeksi didaerah posterior dengan anestesi lokal disarankan jika diperlukan analgesia untuk dinding abdomen anterior dan lateral. Namun, sebagian besar cabang kulit lateral muncul sebelum saraf utama memasuki TAP, dan hanya cabang dari T11 dan T12 yang memiliki jalur pendek di dalam atau melalui TAP. Untuk blokade cabang kulit lateral, blok TAP hanya dapat menutupi cabang kulit T11 dan T12 bahkan dengan injeksi yang lebih posterior. Berdasarkan distribusi cabang T9-T12, pendekatan lateral dapat dilakukan pada linea midaksilaris antara margin kosta dan krista iliaka dapat memberikan analgesia periumbilikal dan infraumbilikal, sedangkan pendekatan posterior yang dilakukan dari posterior ke linea midksilaris memiliki potensi untuk memberikan beberapa derajat analgesia untuk dinding abdomen bagian lateral. Penyebaran paravertebra dari T5 ke L1 telah dilaporkan hanya dengan blok TAP posterior. Cabang-cabang L1, yang menjadi saraf ilioinguinal dan iliohipogastrik, melewati TAP dekat bagian anterior krista iliaka. Dengan demikian, blok TAP pada level ini mirip dengan blok saraf ilioinguinal dan iliohipogastrik. Namun, blok saraf ilioinguinal/ iliohipogastrik langsung adalah pilihan yang lebih baik dibandingkan dengan blok TAP jika hanya analgesia L1 yang diperlukan. ${ }^{5}$ Penyebaran injeksi di TAP mungkin dipengaruhi oleh variasi anatomi, volume yang diinjeksikan, dan pilihan pendekatan. Untuk mencapai kualitas analgesia terbaik tanpa meningkatkan volume dan toksisitas sistemik terkait, penting untuk memilih metode yang paling tepat dengan mempertimbangkan distribusi saraf segmental. ${ }^{5}$

Ada empat otot berpasangan di dinding abdomen anterolateral yaitu rektus abdominis, transversus abdominis, oblikus interna dan oblikus eksterna. Rektus abdominis berjalan sejajar di garis tengah dan dipisahkan oleh linea alba. Tiga oto

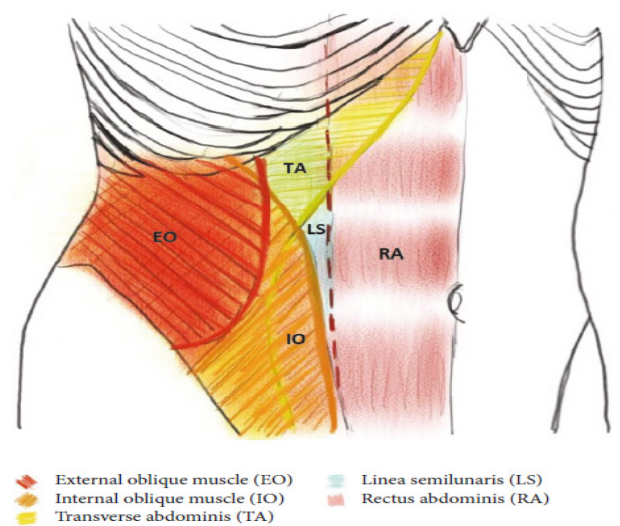

Gambar 2. struktur otot dinding abdomen anterolateral. RA: rektus abdominis; TA: transversus abdominis; IO: obliks interna; EO: oblikus eksterna; LS: linea semilunaris. Garis putus-putus merah: perbatasan lateral rektus abdominis. ${ }^{5}$

lainnya adalah otot-otot yang terletak di lateral yaitu transversus abdominis, oblikus internus dan oblikus eksternus, berurutan dari profunda ke superfisial, dan terutama terkait dengan blok TAP. Tiga otot saling melapisi satu sama lain di abdomen lateral dan berakhir medial sebagai aponeurosis yang disebut linea semilunaris, yang lateral ke rektus abdominis. Pleksus TAP terletak pada transversus abdominis. Oleh karena itu, injeksi lokal intramuskuler mungkin juga memiliki beberapa efek analgesik. ${ }^{5}$

\section{Klasifikasi}

TAP adalah ruang anatomi potensial diantara transversus abdominis dan oblikus internus (atau rektus abdominis), dan blok bidang dengan infiltrasi TAP disebut sebagai blok TAP. Ada beberapa pendekatan yang berbeda untuk blok TAP yang dipandu USG. Tidak seperti blok saraf perifer spesifik, blok TAP adalah "blok bidang" non dermatomal. Bahkan dengan teknik USG yang sama, tingkat penyebaran anestesi lokalnya dapat bervariasi karena variasi anatomi individu. Dari berbagai pendekatan dikategorikan menjadi empat kelompok yang terdiri dari blok TAP subkostal, oblik subkostal, lateral dan posterior TAP. Klasifikasi ini didasarkan pada saraf spinal yang terlibat dari pada posisi transduser, meskipun semua cabang anterior bergabung pada TAP, namun setiap saraf segmental menginervasi 
daerah yang berbeda. T6-T8 menginervasi area di bawah margin xiphoid dan sejajar ke kosta, T9-T12 menginervasi daerah periumbilikal dan dinding abdomen bagian lateral serta krista iliaka, dan L1 akan menginervasi abdomen bagian anterior dekat dengan daerah inguinal dan paha. ${ }^{5}$

Klasifikasi blok TAP berdasarkan pada sistem nomeklatur terpadu ditunjukkan pada tabel 2.1. Banyak pendekatan telah disarankan untuk memberikan analgesia pada abdomen bagian atas, seperti oblik subkostal, subkostal, atau subkostal atas. Namun, mereka sangat mirip di daerah dimana deposit anestesi lokal kecuali untuk pendekatan oblik subkostal, yang mencakup abdomen bagian atas dan bawah menggunakan teknik hidrodiseksi. ${ }^{5}$ Blok TAP midaksilaris atau lateral dilakukan dengan menempatkan transduser pada atau anterior ke linea aksilaris antara margin kosta dan krista iliaka. Hal ini dapat memberikan analgesia pada dinding abdomen bagian bawah dari linea mediana anterior ke linea midklavikula. Dibandingkan dengan blok TAP lateral, blok TAP posteriormendekatiteknikTAPgandapadasegitiga petit lumbal dengan menginjeksikan anestesi lokal ke permukaan apponeurosis transversus abdominis dan menawarkan analgesia yang lebih baik dan lebih lama dari pada pendekatan lateral. Selain itu, injeksi subkostal tidak selalu memberikan analgesia pada cabang kulit bagian lateral dari saraf segmental, pendekatan posterior dengan menginjeksian dari posterior ke linea midaksilaris dapat memberikan analgesia yang lebih baik ke dinding abdomen bagian lateral. ${ }^{5}$

Blok TAP ganda, yang secara teknis menggabungkan subkostal dengan lateral, memberikan cakupan yang lebih luas untuk dinding abdomen bagian atas dan bawah. Dengan membius kedua pleksus, yaitu pleksus TAP superior (pleksus interkostal, yang terdiri dari gabungan cabang besar anterolateral) dan pleksus TAP inferior (arteri iliaka sirkumfleksa profunda) (gambar 1.(a)). Pendekatan dengan jarum panjang lateral ke medial dapat mencakup T7/8 sampai L1. Jika blok TAP ganda dilakukan secara bilateral, itu disebut dengan blok TAP ganda bilateral dan mencakup dinding abdomen anterior dengan empat kuadrannya. ${ }^{5}$ Seperti disebutkan sebelumnya, blok TAP oblik subkostal adalah blok TAP subkostal yang dimodifikasi. Dengan hidrodisesksi TAP sepanjang garis oblik subkostal (dari xiphoid menuju bagian anterior krista iliaka), larutan anestesi menyebar melintasi lokasi saraf T6-L1 dan dengan demikian berpotensi mencakup kedua bagian dinding abdomen baik atas maupun bawah. Karena hanya membutuhkan satu penetrasi melalui

Tabel 1. Klasifikasi blok TAP yang dipandu ultrasound dan area yang diinervasi. ${ }^{5}$

\begin{tabular}{|c|c|c|c|}
\hline \multirow{2}{*}{$\begin{array}{l}\text { Pendekatan } \\
\text { Subkostal }\end{array}$} & \multicolumn{2}{|c|}{ Segmen utama nervus torakolumbal } & \multirow{2}{*}{\begin{tabular}{l}
\multicolumn{1}{c}{ Area inervasi } \\
Abdomen bagian atas tepat \\
dibawah xiphoid dan sejajar \\
dengan margin kosta
\end{tabular}} \\
\hline & T6-9 & Cabang kulit anteror & \\
\hline Lateral & $\mathrm{T} 10-12$ & Cabang kulit anterior & $\begin{array}{l}\text { Dinding abdomen bagian } \\
\text { anterior di daerah infaum- } \\
\text { bilikal, dari linea mediana } \\
\text { anterior ke linea midklavi- } \\
\text { kula }\end{array}$ \\
\hline Posterior & T9-12 & $\begin{array}{l}\text { Cabang kulit anterior } \\
\text { (memungkinkan cabang } \\
\text { kulit lateral) }\end{array}$ & $\begin{array}{l}\text { Dinding abdomen bagian } \\
\text { anterior di daerah infraum- } \\
\text { bilikal dan kemungkinan } \\
\text { dinding abdomen bagian } \\
\text { lateral antara margin kosta } \\
\text { dan krista iliaka }\end{array}$ \\
\hline Oblik subkostal & T6-L1 & Cabang kulit anterior & $\begin{array}{l}\text { Abdomen bagian atas dan } \\
\text { bawah }\end{array}$ \\
\hline
\end{tabular}


pendekatan subkostal tetapi mencakup baik pleksus TAP superior maumpun inferior seperti TAP ganda, tidak dapat diklasifikasikan ke dalam salah satu dari kedua kelompok ini secara tepat. Dengan demikian, blok TAP oblik subkostal harus dikategorikan sebagai teknik independen dan spesifik untuk blok TAP (Tabel 2.1). karena blok TAP subkostal yang lebih rendah mencakup area yang sama dengan blok TAP lateral dan tidak memberikan analgesia pada dermatom T78, maka blok TAP subkostal yang lebih rendah dikategorikan sebagai blok TAP lateral. ${ }^{5}$

Blok TAP posterior memiliki manifestasi yang berbeda dibandingkan dengan blok TAP lateral, termasuk efek analgesik dan durasinya. Baik dengan pendekatan lateral maupun subkostal akan menghasilkan penyebaran warna dari posterior ke linea midaksilaris dan dengan demikian menjadikan pengecualian pada cabang saraf kulit lateral, yang mungkin dapat dicegah dengan pendekatan posterior. Cabang-cabang L1 membelah menjadi saraf ilioinguinal dan iliohipogastrik. Jika analgesia pada dermatom L1 adalah fokus utama, maka disarankan untuk menargetkan cabang L1 yang spesifik seperti blok saraf ilioinguinal dan iliohipogastrik yang

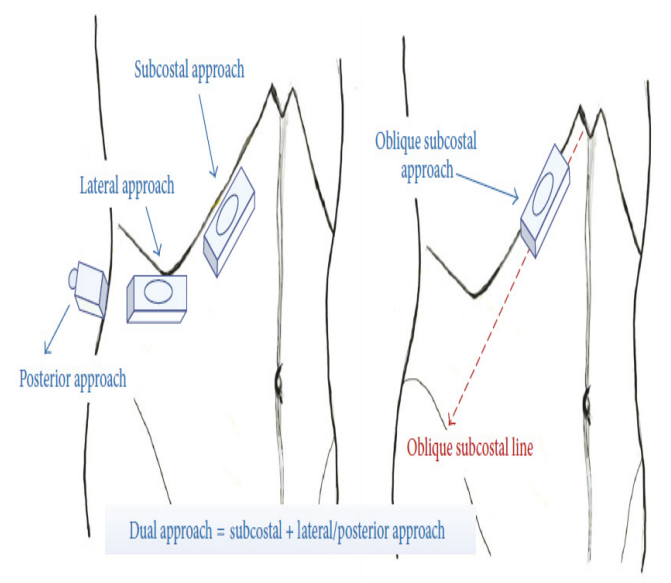

Posisi transduser dari setiap blok TAP yang dipandu USG ditunjukkan pada Gambar 3. dan gambar USG yang sesuai ditunjukkan pada gambar $4 .^{5}$

Gambar 3. Empat pendekatan blok transversus abdominis plane (TAP) dengan panduan ultrasound. Garis merah putus-puts menunjukan garis oblik subkostal, dari xiphoid ke bagian anterior krista iliaka. $^{5}$ dapat memberikan analgesia yang lebih spesifik dan lebih baik dari pada blok TAP. Blok pada kuadratur lumborum juga merupakan alternatif yang menjanjikan untuk memblok cabang L1 yang berjalan di atas permukaan kuadratus lumborum. Blok bidang fasia transversalis yang dipandu USG juga memberikan analgesia pada dermatom L1, namun memerlukan injeksi yang lebih dalam dari pada blok TAP dan berisiko untuk kelemahan motorik yang sulit diantisipasi karena penyebaran ke pusat dan proksimal menuju psoas mayor. ${ }^{5}$

\section{Teknik}

Kemajuan saat ini dalam teknik berkelanjutan untuk mengatasi keterbatasan blok TAP dengan hanya sekali injeksi telah dibahas. Pasien ditempatkan dalam posisi terlentang untuk semua pendekatan ini, kecuali untuk sedikit lateralisasi pada pendekatan posterior dalam beberapa kasus. ${ }^{5}$ Panduan USG sekarang dianggap sebagai standar emas untuk blok saraf perifer. Untuk melakukan blok TAP yang dipandu USG, identifikasi TAP adalah prioritas pertama. Disarankan langkahlangkah pencarian TAP dengan: (1) letakan transduser secara melintang tepat dibawah prosesus xiphoid dan cari hubungan antara rektus abdominis dan linea alba. (2) putar transduser secara oblik dan pindahkan ke lateral, sejajar dengan margin kosta. Pada tingkat ini, TAP adalah bidang antara rektus abdominis dan transversus abdominis, atau TAP tidak ada di sini karena transversus abdominis berakhir di ujung lateral rektus abdominis pada beberapa pasien. (3) pindahkan transduser sepanjang margin kosta lebih lateral sampai aponeurosis dari linea semilunaris, yaitu lateral dari rektus abdominis. Oblikus interna dan oblikus eksterna terletak disebelah lateral dari linea semilunaris. Sehingga dapat mulai mengidentifikasi tiga lapisan otot yaitu transversus abdominis, oblikus interna, dan oblikus eksterna (dari profunda ke superfisial). TAP terletak tepat diatas transversus abdominis. (4) pindahkan transduser lebih lateral ke linea midaksilaris, dan periksa ke atas dan ke bawah antara margin kosta dengan krista iliaka. Biasanya tiga otot dapat dilihat, dan TAP adalah antara oblikus interna dan transversus abdominis. (5) jika transduser ditempatkan di posterior, maka 

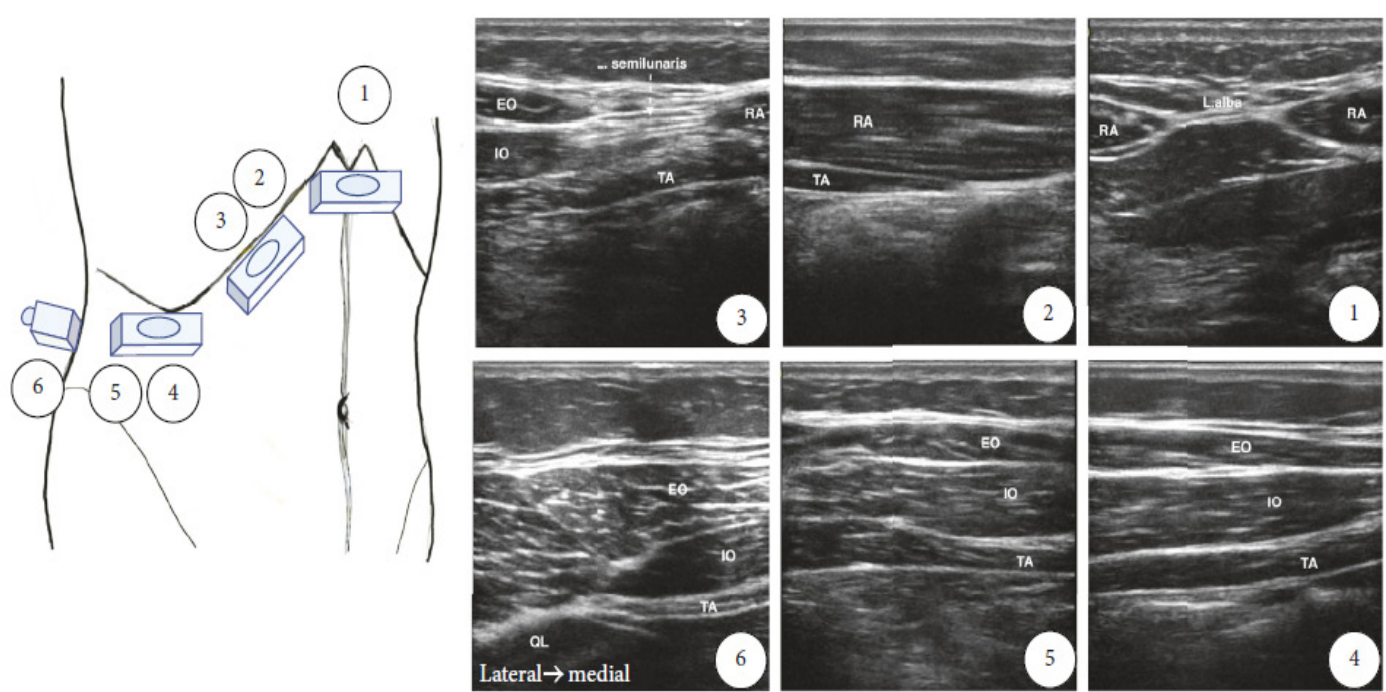

Gambar 4. Identifikasi ultrasonografi pada bidang transversus abdominis. RA: rektus abdominis; TA: transversus abdominis; IO: obliks interna; EO: oblikus eksterna; LS: linea semilunaris. ${ }^{5}$

ditemukan bahwa oblikus interna dan transversus abdominis meruncing menjadi aponeurosis, atau disebut dengan fasia torakolumbalis, yang terhubung ke batas akhir kuadratus lumborum. TAP adalah antara oblikus interna dan transversus abdominis dan berlanjut dengan aponeurosis. Posisi transduser dari setiap blok TAP yang dipandu USG ditunjukkan pada Gambar 3. dan gambar USG yang sesuai ditunjukkan pada gambar $4 .^{5}$
Blok TAP subkostal, seperti yang ditunjukan pada gambar 5.(a) dan dijelaskan dalam langkah (1) dan (2), transversus abdominis diidentifikasikan sebagai lapisan otot yang lebih hipoekoik tepat dibawah rektus abdominis. Endapan anestesi lokal dimulai antara transversus abdominis dan rektus abdominis, medial ke linea semilunaris (gambar 5.(b)). Jika transversus abdominis berakhir di ujung lateral rektus abdominis, anestesi lokal dapat diendapkan antara transversus abdominis dan oblikus interna lateral ke linea semilunaris,

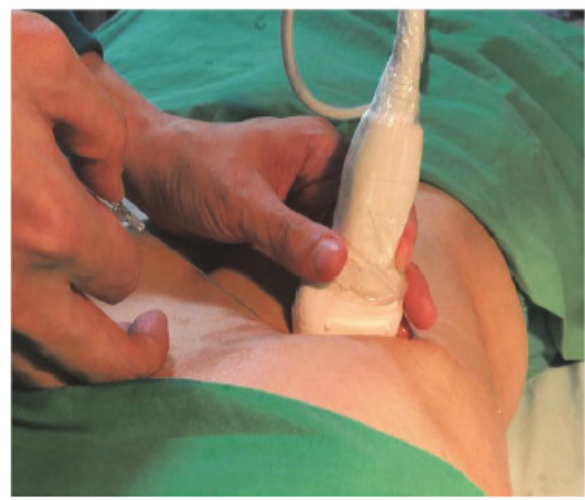

(a)
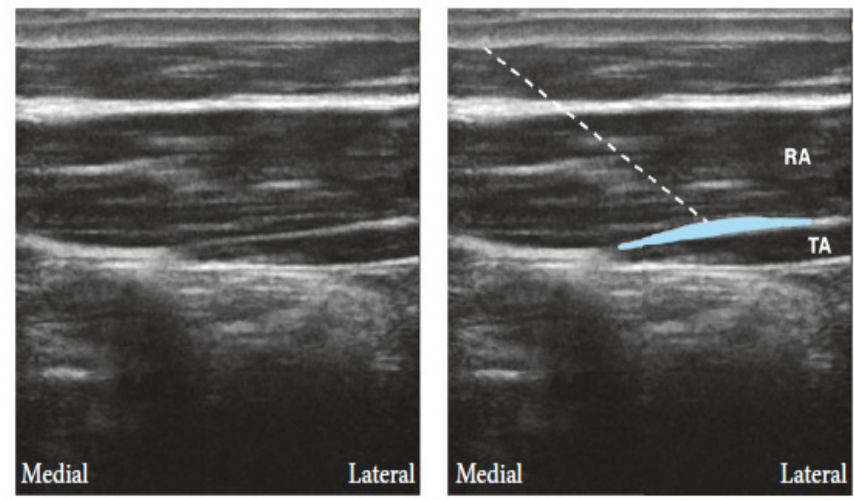

(b)

Gambar 5. Pendekatan subkostal blok transversus abdominis plane (TAP). (a) posisi transduser dan arah jarum, transduser sejajar dengan margin kosta didekat xiphoid, jarum dimasukan ke dalam bidan. (b) Jadilah gambar USG yang sesuai. TAP berada di antara rektus abdominis dan transversus abdominis, dan anestesi lokal tersebar di bidang ini untuk menutupi pleksus TAP superior. Garis putus-putus putih: lintasan jarum; area biru muda: tempat penyebaran anestesi lokal; RA: rektus abdominis; TA: transversusabdominis 


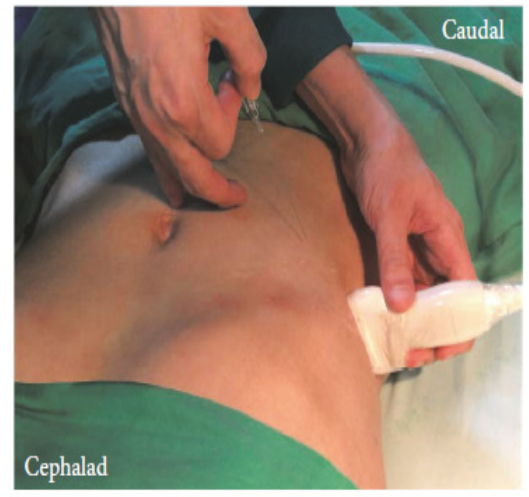

(a)
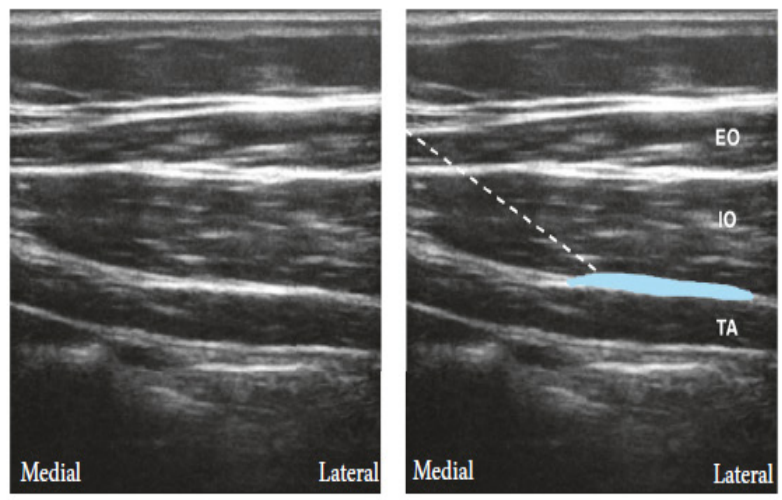

(b)

Gambar 6. Pendekatan lateral blok transversus abdominis plane (TAP). (a) posisi transduser dan lintasan jarum, transduser berada di dekat atau di linea midaksilaris antara margin kosta dan krista iliaka, jarum dimasukan ke dalam bidang. (b) jadilah gambar USG yang sesuai, TAP berada di antara oblikus internus dan transversus abdominis, dan anestesi lokal tersebar di bidang ini untuk menutupi pleksus TAP inferior. Garis putus-putus putih: lintasan jarum; area biru muda: tempat penyebaran anestesi lokal; IO oblikus interna; EO: oblikus eksterna; TA: transversus abdominis. ${ }^{5}$

tetapi mungkin lebih baik memasukan injeksi dari bawah rektus abdominis ke sisi lateral untuk mencapai tingkat keberhasilan yang lebih tinggi. ${ }^{5}$ Gambar 5. Pendekatan subkostal blok transversus abdominis plane (TAP). (a) posisi transduser dan arah jarum, transduser sejajar dengan margin kosta didekat xiphoid, jarum dimasukan ke dalam bidan. (b) Jadilah gambar USG yang sesuai. TAP berada di antara rektus abdominis dan transversus abdominis, dan anestesi lokal tersebar di bidang ini untuk menutupi pleksus TAP superior. Garis putus-putus putih: lintasan jarum; area biru muda: tempat penyebaran anestesi lokal; RA: rektus abdominis; TA: transversusabdominis. ${ }^{5}$ Blok

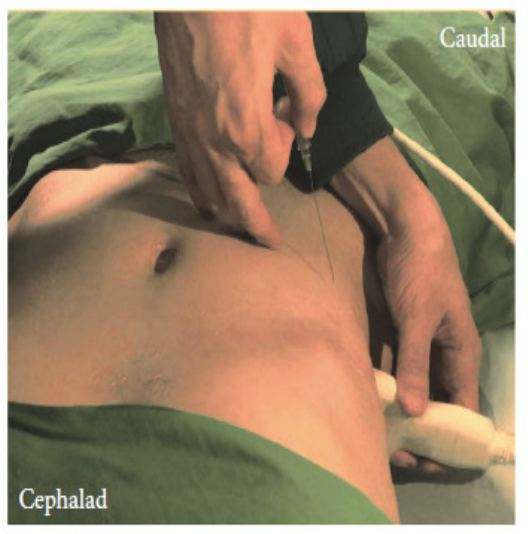

(a)
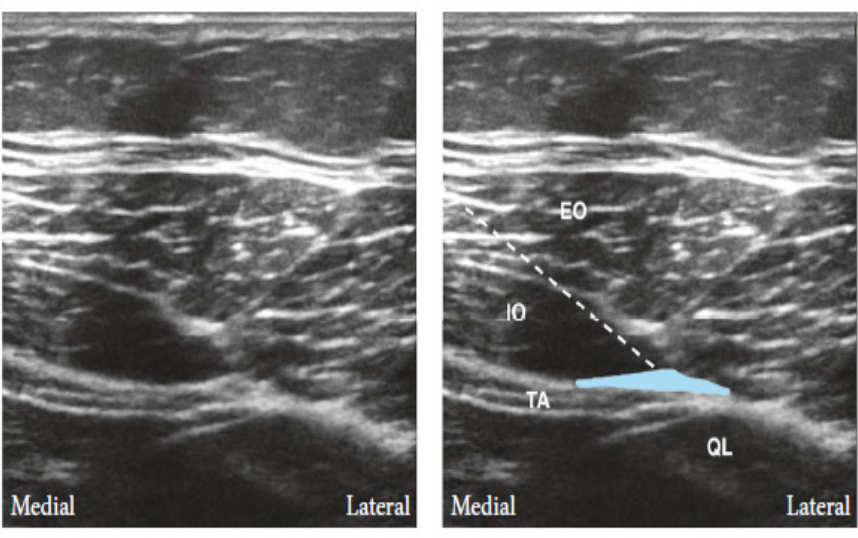

(b)

Gambar 7. Pendekatan posterior blok transversus abdominis plane (TAP). (a) posisi transduser dan lintasan jarum, transduser ditempatkan posterior ke linea midaksilaris antara margin kosta dan krista iliaka, jarum dimasukan ke dalam bidang. (b) jadilah gambar USG yang sesuai, di posterior transversus abdominis berubah menjadi aponeurosis, dan kuadratus lumborum dapat dilihat di posteromedial ke aponeurosis, tempat injeksi berada di TAP antara oblikus interna dan transversus abdominalis posterior ke linea midaksilaris dan dekat aponeurosis. Garis putus-putus putih: lintasan jarum; area biru muda: tempat penyebaran anestesi lokal; IO oblikus interna; EO: oblikus eksterna; QL: kuadratus lumborum; TA: transversus abdominis. ${ }^{5}$ 
TAP lateral, pada langkah (4) dapat diidentifikasi tiga lapisan otot pada linea mid aksilaris antara margin kosta dengan krista iliaka. Setelah mengukur kedalaman TAP, jarum disisipkan jauh dari transduser pada jarak yang sama sesuai dengan prinsip membuat jarum pada bidang blok anestesi regional dalam (gambar 6.(a)). Jarum di majukan ke transversus abdominis dan ditarik kembali secara bertahap dengan aspirasi teratur dan kemudian bidang dihidrogenasikan sampai terdapat tanda mata, sebuah elips yaitu penyebaran hipoekoik anestesi lokal. Kalau tidak, hal itu juga logis untuk meninggalkan anestesi lokal di bawah fasia untuk memastikan analgesia yang optimal karena saraf terikat pada transversus abdominis. Jika opasiti merata muncul dalam oblikus interna, maka mengindikasikan injeksi intramuskular atau anestesi lokal tersebut tidak memisahkan fasia dengan baik, dan ujung jarum harus direposisi. Namun, injeksi intramuskular dari transversus abdominis mungkin masih memberikan beberapa efek analgesia. Pengaturan setengah-udara juga dapat mengidentifikasi bidang fasia yang benar menggunakan uji volume injeksi dan mencegah cidera neurologis insidental. Gambar 6.(b) menunjukan gambar USG dari blok TAP lateral. ${ }^{5}$

Blok TAP posterior, dimana pendekatannya mirip dengan lateral, tetapi transduser USG bergerak lebih posterior seperti yang ditunjukkan pada gambar 7.(a). Ini untuk melihat titik dimana transversus abdominis berakhir, seperti yang dijalaskan pada langkah (5). Saat pemindaian posterior, transversus abdominis keluar dan berubah menjadi aponeurosis. Kuadratus lumborum dapat dilihat posteromedial ke aponeurosis (gambar 7.(b)), ini merupakan tempat injeksi superfisial untuk aponeurosis dekat kuadratus lumborum. ${ }^{5}$

Blok TAP oblik subkostal, yaitu dimodifikasi dari blok TAP subkostal. Tidak seperti pendekatan lain, diperlukan jarum yang lebih panjang (15$20 \mathrm{~cm}$ ) dan volume anestesi yang lebih besar (40$80 \mathrm{ml}$ ). Garis oblik subkostal memanjang dari xiphoid menuju bagian krista iliaka anterior dan berpotensi untuk memblok saraf T6-L1 dalam TAP(Gambar 3.). Dengan demikian, anestesi lokal yang diinjeksikan dalam TAP sepanjang garis ini memberikan analgesia dinding abdomen atas dan bawah, seperti blok TAP ganda. Dibandingkan dengan blok TAP ganda, blok TAP oblik subkostal lebih konsisten mencakup dermatom L1. Hanya diperlukan penetrasi tunggal untuk pendekatan oblik subkostal, namun dibutuhkan sejumlah besar anestesi lokal untuk menghidrolisis TAP sepanjang garis oblik subkostal ipsilateral. Sehingga dapat memberikan analgesia yang lebih menjanjikan untuk operasi abdomen dan mungkin lebih baik dibandingkan dengan pendekatan lateral. Akan tetapi, blok TAP oblik subkostal jauh lebih sulit, dengan membengkokkan jarum pada awalnya dan kemudian memasukan kembali selama memajukan jarum mungkin membantu dalam melakukan blok. ${ }^{5}$

\section{Komplikasi}

Kerusakan viseral karena tusukan peritoneum yang tidak disengaja saat melakukan blok TAP telah banyak dilaporkan. Meskipun risikonya dapat diminimalkan dengan USG, potensi cidera iatrogenik masih ada karena kegagalan dalam membayangkan seluruh jarum selama memajukannya. Komplikasi lain yang dilaporkan dari blok TAP termasuk kejang, aritmia ventrikel, dan kelumpuhan saraf femoralis transien.

Untuk meminimalisir toksisitas sistemik, konsentrasi aliran anestesi lokal harus dipilih ketika menggunakan rejimen dengan volume yang banyak (misalnya, $20 \mathrm{ml}$ secara bilateral) diperlukan untuk untuk keberhasilan blok. Komunikasi yang baik antara dokter anestesi dan dokter bedah juga membantu mencegah overdosis dengan injeksi anestesi lokal berulang setelah blok TAP. Ketersediaan segera emulsi lipid dan terapi darurat lainnya direkomendasikan untuk blok TAP. Kelumpuhan saraf femoralis transien setelah blok TAP diinduksi oleh kesalahan pengendapan lokal anestesi antara transversus abdominis dengan fasia transversalis. Karena saraf femoralis terletak pada bidang jaringan yang sama, maka anestesi lokal sedikitpun seperti $1 \mathrm{ml}$ yang mengalir ke posteromedial dapat mengelilingi saraf femoralis. Menggunakan panduan USG untuk menemukan ujung jarum akan membantu mengidentifikasi TAP dan menghindari penyebaran anestesi lokal ke saraf femoralis. $^{5}$ 


\section{Efektivitas Blok Transversus Abdominis Plane Pasca Operasi Caesar}

Terdapat peningkatan bertahap dalam jumlah operasi caesar yang dilakukan di seluruh dunia. Ini adalah tren global dan bertanggung jawab atas lebih dari seperempat dari seluruh kelahiran di dunia. Rasa sakit dan kesulitan yang substansial diantisipasimengikutiprosedurbedahbesarseperti operasi caesar. Manajemen nyeri pasca operasi yang efektif sangat penting dalam subkelompok ini untuk memfasilitasi ambulasi dini, perawatan bayi, dan ikatan ibu-bayi. ${ }^{6}$ Komponen penting dari rasa sakit dan ketidaknyamanan disebabkan oleh insisi dinding abdomen. Teknik anestesi regional seperti infiltrasi lokal anestesi, blok saraf ilioinguinal, blok bidang abdomen, dan blok transversus abdominis plane (TAP) digunakan untuk mengurangi rasa sakit dari insisi dinding abdomen. Dinding abdomen anterolateral telah dijelaskan diinervasi oleh saraf torakolumbal T6 hingga L1 yang melintasi bidang lapisan antara otot transversus abdominis dan oblikus internus. Blok TAP adalah teknik anestesi regional dimana agen lokal anestesi diinjeksikan ke TAP untuk memblokir saraf sensorik yang memasok dinding abdomen anterior.

Blok TAP telah menunjukkan manfaat analgesik yang lebih baik dibandingkan dengan plasebo dalambanyakpercobaan prospektifacakterkontrol untuk operasi caesar. ${ }^{6}$ Blok TAP merupakan teknik anestesi regional yang relatif baru, dimana serabut saraf aferen yang menginervasi dinding abdomen bagian anterolateral diblokir dengan mengguakan anestesi lokal di bidang transversus abdominalis. TAP sebagai bagian dari rejimen analgesik multimodal pasca operasi secara perlahan sudah mendapatkan popularitas. Potensinya dalam meningkatkan kualitas dan durasi analgesia setelah berbagai operasi abdomen bawah sudah tidak bisa dipungkiri lagi. Penelitian membuktikan bahwa blok TAP memperpanjang durasi analgesia $( \pm 6,5$ jam $){ }^{6}$ Penelitian yang dilakukan pada kelompok pasien yang diberikan blok TAP pasca operasi caesaria mendapatkan hasil skor VAS pada saat masuk ruang pemulihan, keluar dari ruang pemulihan, dan pada jam pertama, kedua, ketiga, keempat, keenam, dan keduabelas pasca operasi caesaria secara signifikan lebih rendah bila dibandingkan dengan kelompok pasien yang tidak menerima aplikasi tambahan setelah anestesi spinal $(p<0,05)$. Selain itu, jumlah penggunaan tramadol yang digunakan di ruang pemulihan dan selama 24 jam pasca operasi serta secara signifikan kelompok pasien dengan blok TAP lebih rendah dibandingkan dengan kelompok kontrol $(p<0,05)$. Serta, skor kepuasan pasien yang dinilai pada 24 jam pasca operasi secara signifikan kelompok pasien dengan blok TAP lebih tinggi dibandingkan dengan kelompok kontrol $(p<0,05)$. Hasil ini serupa dengan penelitian menggunakan blok TAP yang dipandu dengan USG, yaitu menurunkan intensitas nyeri dalam 24 jam pertama pasca operasi caesar serta menurunkan kebutuhan analgesik lainnya, karena pada kelompok kontrol memerlukan tambahan beberapa dosis injeksi tramadol pada 24 jam setelah operasi caesar. ${ }^{7,8}$ Penelitan yang dilakukan untuk melihat penyebaran injeksi setelah blok TAP menggunakan USG menyatakan bahwa saraf T10-L1 pada bidang transversus abdominalis dapat terpengaruh dengan volume $20 \mathrm{ml}$ lokal anestesi.

Konsentrasi lokal anestesi dapat disesuaikan dengan kondisi pasien, namun alih-alih bergantung pada konsentrasi, blok TAP merupakan metode yang bergantung pada jumlah volume lokal anestesi. Asalkan diberikan volume yang cukup, maka memungkinkan untuk mencapai analgesia yang berlangsung sekitar 24-48 jam. ${ }^{7}$ Dalam sebuah penelitian lain untuk mengevaluasi keefektivan blok TAP pasca operasi caesar diamati bahwa aplikasi blok TAP yang dipandu dengan bantuan USG pada pasien yang menjalani operasi caesar di bawah anestesi spinal mengakibatkan penurunan rasa nyeri, mengurangi konsumsi opioid pada periode pasca operasi dan efek samping terkait opioid, serta peningkatan kenyamanan pasien. Selain itu, secara signifikan meningkatkan akurasi dari penginjeksian anestesi lokal dan mengurangi kejadian efek samping sehingga semakin mempopulerkannya sebagai analgesia blok saraf pasca operasi caesaria. ${ }^{7,9,10}$

Penelitian yang dilakukan dimana melibatkan 
pasien yang menjalani operasi caesar dengan anestesi umum menunjukan bahwa aplikasi blok TAP yang dipandu dengan bantuan USG menghasilkan pengurangan konsumsi morfin dalam 24 jam pertama dan skor VAS pasca operasi yang lebih rendah. Selain itu, evaluasi efektivitas blok TAP yang dilakukan setelah anestesi spinal juga menunjukkan penurunan skor VAS serta konsumsi analgesik yang terkait dengan prosedur. Hasil ini juga konsisten dengan sebuah penelitian meta-analisis tentang manfaat utama dari blok TAP yaitu ditemukannya pengurangan konsumsi morfin pasca operasi caesar dibandingkan dengan pasien yang menerima agen tidak aktif (termasuk plasebo dan perawatan standar). ${ }^{7,11}$ Sebuah meta-analisis yang meninjau 7 penelitian yang melibatkan blok TAP setelah anestesi umum dan 2 penelitian yang melibatkan blok TAP setelah anestesi spinal menyimpulkan bahwa aplikasi blok TAP memiliki kontribusi yang signifikan dalam manajemen nyeri pasca operasi caesar dalam kasus anestesi spinal yang tidak melibatkan penambahan injeksi opioid intratekal. Adapun aplikasi anestesi spinal yang melibatkan penambahan opioid, dalam penelitian ini tidak menunjukan efek yang signifikan dari blok TAP. ${ }^{7}$ Penelitian acak lain yang menggabungkan efektivitas morfin intratekal terhadap blok TAP menunjukkan bahwa pasien yang mendapatkan injeksi morfin intratekal memiliki skor VAS yang lebih rendah pada saat istirahat dan selama beraktivitas serta mengurangi konsumsi analgesik tambahan bila dibandikan dengan pasien yang mendapatkan blok TAP. Namun, mereka mengalami lebih banyak efek samping yang terkait dengan morfin. Dalam meta-analisis mereka juga termasuk 312 kasus, disimpulkan bahwa aplikasi blok TAP dapat dengan mudah dilakukan pada kasus pasien yang memiliki kontraindikasi untuk pemberian opioid intratekal. ${ }^{7,12}$

Pada penelitian yang juga dilakukan untuk mengevaluasi efektivitas dan keamanan blok TAP dengan panduan USG pasca operasi ceasar mendapatkan hasil bahwa kelompok pasien yang diberikan blok TAP secara signifikan memiliki skor nyeri yang lebih rendah dibandingkan dengan kelompok pasien yang hanya menerima analgesia rutin pasca operasi caesar. Selain itu, didapatkan fakta bahwa sebagian besar pasien dalam kelompok kontrol yang hanya menerima analgesia rutin pasca operasi caesar menginginkan analgesia tambahan, yang secara tidak langsung menunjukkan manfaat analgesia dari blok TAP atas kelompok kontrol. ${ }^{10}$ Penelitian yang membandingkan pendekatan lateral dan posterior pada blok TAP yang dipandu USG untuk analgesia pasca operasi caesar dengan anestesi spinal menunjukkan bahwa pendekatan posterior lebih unggul dari pada pendekatan lateral terutama pada waktu istirahat. ${ }^{7}$ Banyak penelitian telah menunjukkan efektivan blok TAP untuk menghilangkan rasa nyeri pasca operasi caesar. Salah satunya menemukan bahwa semua saraf yang terlibat pada nyeri pasca operasi ceasar akan melintasi TAP di linea midaksilaris. Oleh karena itu pendekatan oblik subkostal dari blok TAP muncul sebagai analgesia yang lebih baik pada keempat kuadran abdomen, baik diatas maupun dibawah umbilikus. ${ }^{9}$

Berbagai aditif dapat ditambahkan ke anestesi lokal untuk memperpanjang durasi analgesia yang dihasilkan dengan blok saraf. Clonidine, dexmedetomidine, fentanyl, dan sufentanil merupakan aditif yang umum digunakan. Telah ditunjukkan dalam berbagai penelitian bahwa penambahan seperti clonidine ke lokal anestesi dapat meningkatkan aksi blok saraf perifer. ${ }^{10}$ Kriteria evaluatif yang paling penting mengenai kepuasan pasien adalah sensasi nyeri. Manajemen nyeri pasca operasi yang efektif memiliki arti penting untuk evaluasi ini. Konsisten dengan literatur, yaitu kepuasan pasien secara signifikan lebih tinggi pada kelompok blok TAP. ${ }^{7}$ Blok lain dimana blok TAP sering dibandingkan adalah infiltrasi luka dan blok saraf II-IH. Penelitian yang membandingkan blok TAP dengan infiltrasi luka untuk analgesia pasca operasi caesar menunjukkan bahwa blok TAP lebih baik dibandingkan dengan infiltrasi luka., ${ }^{73}$ Penelitian yang juga membandingkan efektivitas blok TAP dengan blok II-IH pada pasien pasca operasi caesar mendapatkan hasil bahwa semua pasien dalam kedua kelompok memerlukan satu dosis tambahan analgesik berupa injeksi natrium diklofenak 50mg intravena, tetapi kemudian 57\% pasien tidak memerlukan analgesik tambahan 
lebih lanjut pada kelompok blok TAP, sedangkan pada kelompok blok II-IH hanya 13\% yang tidak memerlukan tambahan analgesik lebih lanjut. Dengan demikian, blok TAP memberikan penghilang rasa nyeri pasca operasi yang lebih baik dari pada blok saraf II-IH sebagai bagian dari rejimen multimodal dalam operasi caesar. Selain itu, ketika jarum dimajukan melintasi bidang neurofasial dari dinding abdomen anterior, blok TAP secara signifikan meningkatkan efek analgesik. ${ }^{14,15}$

Keterbatasan untuk intervensi blok TAP adalah keterampilan yang lebih besar diperlukan untuk seorang dokter anestesi, kemungkinan keterlambatan pergantian pasien merupakan sebagai waktu tambahan yang diperlukan untuk mengelola blok TAP, serta juga memerlukan peralatan yang canggih seperti USG. Selain itu, blok TAP buta dikaitkan dengan komplikasi seperti kejadian suntikan ke intraperitoneal maupun intravaskular. Namun dengan menggunakan panduan USG, maka dapat mengakuratkan deposisi dari anestesi lokal dibidang neurovaskular dengan benar dan menghindari komplikasi terkati prosedur., ${ }^{9}$

\section{Simpulan}

Blok TAP yang dipandu dengan bantuan USG merupakan metode yang aman dan efektif untuk memberikan analgesia pasca operasi caesar sebagai bagian dari rejimen multimodal, serta dikaitkan dengan pengurangan konsumsi opioid, dan peningkatan kepuasan pasien dibandingkan dengan perawatan standar pasca operasi dan teknik analgesik lainnya seperti infiltrasi luka, blok epidural, dan blok ilioinguinal-iliohipogastrik.

\section{Daftar Pustaka}

1. Arroyo-Fernández FJ, Calderón Seoane JE, Torres Morera LM. Strategies of analgesic treatment after cesarean delivery. Current state and new alternatives. Rev Española Anestesiol y Reanim (English Ed. 2020;

2. Carvalho B, Butwick AJ. Postcesarean delivery analgesia. Best Pract Res Clin Anaesthesiol. 2017;31(1):69-79.
3. Kerai S, Saxena KN, Taneja B. Post-caesarean analgesia: What is new? Indian J Anaesth. 2017;61(3):200-14.

4. Ahemed SA, Denu ZA, Getinet Kassahun H, Yilikal Fentie D. Efficacy of Bilateral Transversus Abdominis Plane and Ilioinguinal-Iliohypogastric Nerve Blocks for Postcaesarean Delivery Pain Relief under Spinal Anesthesia. Anesthesiol Res Pract. 2018;2018.

5. Tsai HC, Yoshida T, Chuang TY, Yang SF, Chang CC, Yao HY, et al. Transversus Abdominis Plane Block: An Updated Review of Anatomy and Techniques. Biomed Res Int. 2017;2017:3-9.

6. John R, Ranjan R, Ramachandran $\mathrm{T}$, George S. Analgesic efficacy of transverse abdominal plane block after elective cesarean delivery - Bupivacaine with fentanyl versus bupivacaine alone: A randomized, doubleblind controlled clinical trial. Anesth Essays Res. 2017;11(1):181.

7. Karatepe U, Ozer AB. Evaluation of postoperative analgesic efficacy of transversus abdominis plane block in patients who underwent caesarian section under spinal anesthesia. Biomed Res. 2018;29(10):2101-5.

8. Ashraf V, Yasrab M, Shahid S. Efficacy of Ultrasound Guided Bilateral Transversus Abdominis Plane Block for The Acute PostOperative Pain Relief in the Obstetrics and Gynecological surgeries in First 24 Hours. 2020;70(1):91-5.

9. Dwivedi D, Bhatnagar V, Goje H, Ray A, Kumar P. Transversus abdominis plane block: A multimodal analgesia technique - Our experience. J Mar Med Soc. 2017;19(1):38.

10. Leeladharan S, Puthenveettil N, Rakhi B, Nair S, Kumar L. Analgesic efficacy and safety of ultrasound guided transverse abdominis plane block in postcesarean section patients-A randomized control trial. J Obstet Anaesth 
Crit Care. 2020;10(1):16.

11. Ma N, Duncan JK, Scarfe AJ, Schuhmann $\mathrm{S}$, Cameron AL. Clinical safety and effectiveness of transversus abdominis plane (TAP) block in post-operative analgesia: a systematic review and meta-analysis. J Anesth. 2017;31(3):432-52.

12. Gao Y, Guo M, Du C, Zhang H, Zhang H, Gharaei H. Clinical study of ultrasoundguided transversus abdominis plane block for analgesia after cesarean section. Med (United States). 2019;98(41).

13. Görkem Ü, Koçyiğit K, Toğrul C, Güngör T. Comparison of bilateral transversus abdominis plane block and wound infiltration with bupivacaine for postoperative analgesia after cesarean delivery. J Turkish Ger Gynecol Assoc. 2017;18(1):26-32.

14. Kiran Lv, Sivashanmugam T, Kumar VH, Krishnaveni N, Parthasarathy S. Relative efficacy of ultrasound-guided ilioinguinaliliohypogastric nerve block versus transverse abdominis plane block for postoperative analgesia following lower segment cesarean section: A prospective, randomized observer-blinded trial. Anesth Essays Res. 2017;11(3):713.

15. Jin Y, Li Y, Zhu S, Zhu G, Yu M. Comparison of ultrasound-guided iliohypogastric/ ilioinguinal nerve block and transversus abdominis plane block for analgesia after cesarean section: A retrospective propensity match study. Exp Ther Med. 2019;289-95. 